\section{Survey of Master Gardener Use of Native Plants in the Southeastern United States}

\author{
Robert F. Brzuszek ${ }^{1,4}$, Richard L. Harkess ${ }^{2}$, and Lelia Kelly ${ }^{3}$
}

\begin{abstract}
ADDITIONAL INDEX WORDs. marketing, education, landscape
SuMmary. The Master Gardener program is a volunteer horticultural training and an educational outreach program developed and managed by state cooperative extension services. Previous research in the southeastern United States revealed that landscape architects and contractors are increasingly using native plant materials in their projects and this often exceeds regional plant availability. A survey of green industry in the region showed supply is driven by consumer demand and education. To determine if native plant demand is encountered by plant purchasers other than landscape architects, this study evaluates the interest level and market use of native plants by Master Gardeners of six southeastern states. A web-based survey was developed, and Master Gardeners were invited to participate by their state Master Gardener coordinators. The survey included questions on how Master Gardeners use native plants in their home landscape, how they best learn about them, the species they have purchased, and their interest level. A total of 979 Master Gardeners completed the survey. Results revealed that this particular consumer group is enthusiastic about native plants and supports the landscape professionals' claims that marketing for native plants could improve if plants were available at more retail outlets, by having more types (herbaceous plants, shrubs, and trees) and species for sale, and by offering greater quantities of plants.
\end{abstract}

$\mathrm{T}$ The use of native plants is increasing nationally among gardeners and is an emerging niche market for the green industry (Hamill, 2005). The definition for a native plant is not universally accepted, which has resulted in some confusion. The U.S. Fish and Wildlife Service defines native as "with respect to a particular ecosystem, a species that, other than as a result of introduction, historically occurred or currently occurs in that ecosystem" (U.S. Fish and Wildlife Service, 2001), whereas, the U.S. National Park Service's definitions is "native species are defined as all species that have occurred or now occur as a result of natural processes on lands designated as units of the national park system. Native species in a place are evolving in concert with each other" (U.S. National Park Service, 2000). Despite the variation in terminology, common

\footnotetext{
Mississippi Agriculture and Forestry Experiment Station Journal Series No. J-11558.

${ }^{1}$ Department of Landscape Architecture, Mississippi State University, Box 9725, Mississippi State, MS 39762

${ }^{2}$ Department of Plant and Soil Sciences, Mississippi State University, 117 Dorman, Box 9555, Mississippi State, MS 39762

${ }^{3}$ North Mississippi Research and Extension Center, Mississippi State University, Box 1690, Verona, MS 38879

${ }^{4}$ Corresponding author. E-mail: rbrzuszek@lalc.msstate. edu.
}

themes for definitions of native plants typically include that plants are found to occur in distinct natural places without the aid of, or introduction by, humans.

Consumers are increasingly selecting native plants for use in home landscapes for a variety of reasons. Many local, state, and federal agencies are requiring the use of native plants in the landscape (HarmonyFL.com, 2008; Norcini, 2006; Pasco County, 2002), and watering restrictions in drought-affected areas have promoted the native ornamental plant trend (O'Brien, 1996). While demand for native plants has increased nationally (Coffey, 2006; Hamill, 2005), native plants in general remain underused in most residential and commercial landscapes (Norcini, 2006). Norcini (2006) states the following may be reasons for the limited consumer use of native plants: native plants may cost more than non-native species, as they tend to be produced in smaller quantities; there is limited availability through retail and wholesale operations; customers are not as familiar with native species; and the perception that wild plants are not as ornamental as exotic species.

Our previous research evaluated the use of native plants by landscape architects and the nursery industry in the southeastern United States
(Brzuszek and Harkess, 2009; Brzuszek et al., 2007). Native plants are being used by landscape architects and contractors in the region, but this demand is currently exceeding the volume and species available at wholesale nurseries. Landscape architects and contractors appear to be the primary drivers of the southeastern United States native plant market and are using hardy native plant species because of their adaptability and suitability for difficult site conditions (Brzuszek et al., 2007). Both groups perceived consumer interest in natives had risen from a minimal level to moderate interest within the past $\mathbf{5}$ years.

A missing component of the previous research by landscape architects and green industry was an evaluation of native plants by a horticulture consumer group in the southeastern United States. With the exception of Florida, no research has been conducted for the southern United States. As some nursery personnel have indicated, while customers are requesting a particular plant, they are not specifying whether it should be native or not (Brzuszek and Harkess, 2009).

Members of the Master Gardener volunteer program are a knowledgeable plant consumer group. The program is offered in all 50 states, the District of Columbia, and four Canadian provinces (Stephens, 2002). Supported by state cooperative extension services, volunteers receive extensive training in horticultural topics in exchange for community service. As a segment of the gardening public, these volunteers' opinions and talents are often used in research projects, not only as data collectors, but as test subjects. The response of these volunteers to surveys, questionnaires, and plant evaluations is vital to aid researchers and extension educators in evaluating the needs and knowledge of the gardening public.

The objective of this study was to survey the use of native plants among a knowledgeable consumer gardening group in six southeastern states to add to the information from previous surveys of landscape and nursery professionals within the region.

\section{Materials and methods}

Members of the Master Gardener programs in the southeastern United States were identified as 
a knowledgeable plant consumer group for the study, and an online web survey (Dillman, 2007) was developed (Table 1). Question Pro $\subset$ (Survey Analytics, Seattle, WA) was selected as the host website and software to administer this questionnaire due to easy design of questionnaires, the ability to view real-time reports, and the inclusion of an analysis software program for data export.

An e-mail letter of invitation detailing the project was sent to Master Gardener state coordinators in Georgia, Alabama, Mississippi, Louisiana, South Carolina, and Texas. Because the questionnaire asked about native plant species purchased, these six southern states were selected as their climate zones and native plant selection are similar (zones 7 and 8 of the U.S. Department of Agriculture Plant Hardiness Zone Map). The e-mail letter of invitation requested that state coordinators forward an attached request letter to active members of each state's Master Gardener $\mathrm{e}$-mail list. The request letter included a hyperlink to the online web survey address. The request letter e-mails were initially sent on 22 July 2007 and the site was available for survey use until 8 Nov. 2007. The first page of the survey included a short introductory paragraph explaining how to respond to the survey and included a definition of a native plant as a plant originating in the southeastern United States before European settlement (i.e., not brought in from other countries or regions). The survey contained 23 questions in closed- and open-ended formats and asked the respondents' interest in and understanding of native plants, perceptions about their uses of native plants in their home landscape, how they best learn about different plant types, plant species purchased and annual dollar amounts,

Table 1. Questions included on the 2007 southeastern U.S. Master Gardener survey on native plant marketing.

\section{Survey question}

1. Have you purchased a plant for your landscape in the past 5 years?

2. Have you purchased a native plant for your landscape in the past 5 years?

3. Have you purchased more native plants in the past 5 years than in years previously?

4. What was the primary reason that you selected native plants over exotic ornamentals?

5. About how much did you spend on purchasing native plants in 2006?

6. About what proportion of your home landscape includes purchased native plant material?

7. About what proportion of your home landscape includes pre-existing native plant material (conserved on site)?

8. How do you mostly learn now about new types or cultivars of native plants?

9. Which of the following information sources are best for you to learn more about native plant types: new cultivars or usage?

10. What are the top 10 native plant species/cultivars that you have purchased (common name or botanical name)?

11. How would you describe your interest in native plants 5 years ago?

12. How would you describe your interest in native plants today?

13. What is the primary reason that you do not purchase more native plant materials?

14. My general level of understanding of native plants is...

15. At a retail garden outlet, it would be helpful to have native plants displayed by...

16. What is your gender?

17. In what year were you born?

18. What is your highest level of education?

19. What is your race? (Control one or more races to indicate what you consider yourself.)

20. What is the approximate population of the town/city where your home is located?

21. Do you own your home?

22. Please mark or list any horticulture or garden associations that you belong to.

23. Are there native plant species/cultivars that you would purchase if available?

(Please list the common name or botanical name.) and demographic information. To determine if plant species responses were native to the southeastern United States, the online USDA PLANTS Database was used as an authoritative regional reference (USDA, 2008).

A second e-mail of the survey request letter was sent on 13 Sept. 2007 to state coordinators of states where Master Gardeners had been slow to respond. A reminder phone call was placed to one state coordinator due to the continued slow response of Master Gardeners in that state. The collected survey information was analyzed using SPSS (version 13.0; SPSS, Chicago) for frequency and cross-tabulation data of the responses. Cross-tabulations of survey questions were generated to identify relationships between nominal variables. To test the statistical significance of the cross-tabulations, a chi-square test was performed.

When asked the top 10 native plant species Master Gardeners purchased, a large number of plant species resulted. All responses were randomized in an Excel (Microsoft, Redmond, WA) spreadsheet and a random sample of 411 respondents was calculated, resulting in greater than a $95 \%$ confidence level. Although the questionnaire specifically asked for species and not cultivars, some respondents inserted cultivar names. Only the plant species were recorded for the results.

\section{Results and discussion}

The online survey was initiated by 1254 users, and 979 successfully completed the survey $(78.1 \%$ completion rate). Of the respondents (849) who replied to the question of which state Master Gardener program they belong to, Texas returned the most surveys $(44.2 \%)$, followed by Georgia (21.6\%), Louisiana (11.9\%), Mississippi (8.2\%), Alabama (7.2\%), and South Carolina $(6.9 \%)$. These percentages are proportional to the numbers of master gardeners in these states. In 2005, the total number of Master Gardeners in Texas (6000) was roughly equal to all the other survey states combined (6077) (M.H Meyer, personal communication).

The demographic data of the survey respondents indicates that the majority of respondents was female $(83.4 \%)$, white $(96.3 \%)$, completed graduate school or a 4-year college 
degree $(67.9 \%)$, and owned their own home $(98.3 \%)$ located within a smallto medium-sized community fewer than 100,000 people in population $(66.6 \%)$. In addition to being part of the Master Gardener program, $16 \%$ of respondents noted that they were also members of a garden club organization, and 16\% replied that they were members of some other horticulture association $(\mathrm{SD}=0.801)$.

When asked their general level of understanding about native plants, the most popular responses were that they were knowledgeable (47.5\%) or knew something about them (45.2\%) $(\mathrm{SD}=0.632)$. Survey results indicated that Master Gardeners are active plant purchasers. For example, virtually all bought plants within the past 5 years $(99.7 \%)$, including natives $(92.4 \%)$ $(\mathrm{SD}=0.265)$. The range that was most frequently answered when asked about how much they spent in dollars purchasing native plants in 2006 was between $\$ 100$ and $\$ 500$ (32.0\%), followed by $\$ 50$ to $\$ 100(28.6 \%)$ $(\mathrm{SD}=1.292)$. A cross-tabulation comparison between responses of dollars spent to individual states showed that the states of Georgia, South Carolina, and Texas spent more on native plants than respondents in Louisiana, Alabama, and Mississippi (Table 2). Fortyone percent of Master Gardeners responding to the survey indicated $0 \%$ to $20 \%(\mathrm{SD}=1.123)$ of the plants in their home landscapes were native. This included native plants purchased for their landscape as well as preexisting plants conserved on-site. Three percent of the Master Gardeners had landscapes composed of more than $80 \%$ native plantings.

Master Gardeners that responded to this survey have increased their interest in native plants over the past 5 years to an enthusiastic degree. The most frequent answers for their interest level in native plants 5 years ago was moderate $(36.1 \%)$ and their current interest was enthusiastic $(63.1 \%)$ (Fig. 1). This exceeds the interest in native plants by southeastern United States landscape architects and nursery personnel who answered this same question as changing from minimal to moderate within the last 5 years (Brzuszek and Harkess, 2009; Brzuszek et al., 2007). A cross-tabulation comparison of responses of current interest levels by individual states showed no differences between states.
The two predominant reasons nursery personnel responded as to why they do not carry more native species and quantities were a lack of client interest and a lack of client demand (Brzuszek and Harkess, 2009). The majority of landscape architects and nursery professionals noted between $0 \%$ and $20 \%$ of their customers specifically request native plants and a better-informed public would help sell more natives in their nurseries (Brzuszek and Harkess, 2009; Brzuszek et al., 2007).

Table 2. Number of responses per expenditure category reflecting the dollars spent by Master Gardeners on native plants in 2006 in six states as reported on the 2007 southeastern U.S. Master Gardener survey.

\begin{tabular}{lrrrrrrrr}
\hline & & \multicolumn{7}{c}{ Expenditure category (\$) } \\
\cline { 3 - 10 } State & $\begin{array}{c}\text { Responses } \\
\text { (no.) }\end{array}$ & $\mathbf{0}$ & $\mathbf{1 - 1 0}$ & $\mathbf{1 1 - 5 0}$ & $\mathbf{5 1 - 1 0 0}$ & $\mathbf{1 0 1 - 5 0 0}$ & $\mathbf{5 0 1 - 1 0 0 0}$ & $\mathbf{1 0 0 0}$ \\
\hline South Carolina & 38 & 3 & 1 & 7 & 8 & 15 & 3 & 1 \\
Mississippi & 51 & 5 & 3 & 16 & 17 & 8 & 1 & 1 \\
Georgia & 155 & 7 & 2 & 32 & 48 & 53 & 10 & 3 \\
Louisiana & 73 & 10 & 4 & 28 & 13 & 15 & 3 & 0 \\
Texas & 217 & 12 & 5 & 44 & 64 & 70 & 18 & 4 \\
Alabama & 67 & 9 & 1 & 10 & 24 & 17 & 4 & 2 \\
Total & 601 & 46 & 16 & 137 & 174 & 178 & 39 & 11 \\
\hline
\end{tabular}

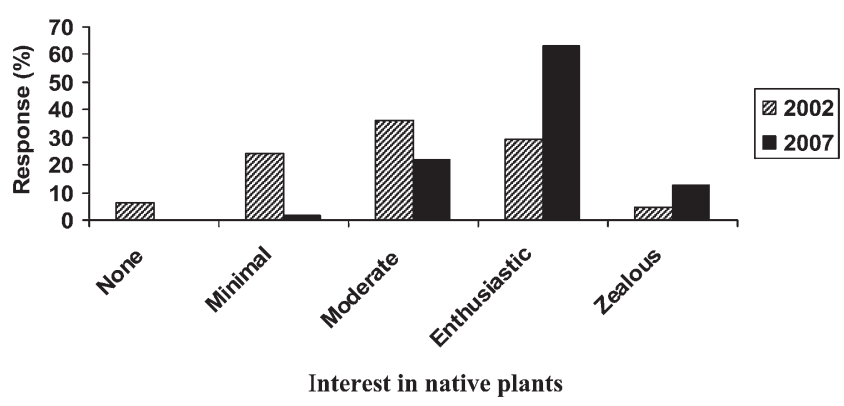

Fig. 1. A comparison of southeastern U.S. Master Gardeners' interest in native plants from 2002 to $2007(\mathrm{SD}=\mathbf{1 . 0})$.

Table 3. Reasons why Master Gardeners do not purchase more native plant materials as reported on a survey of Master Gardeners use of native plants conducted in 2007.

\begin{tabular}{lrr}
\hline $\begin{array}{l}\text { Stated reasons why Master Gardeners do not } \\
\text { purchase more native plants }\end{array}$ & $\begin{array}{c}\text { Responses } \\
\text { (no.) }\end{array}$ & $\begin{array}{c}\text { Valid } \\
\text { responses (\%) }\end{array}$ \\
\hline Cannot find native plants at retail nurseries & 363 & 28.5 \\
Insufficient quantities of native plants available & 199 & 15.6 \\
Not interested in natives & 9 & 0.7 \\
Prices for native plants are not competitive & 55 & 4.3 \\
Not enough types of native plants are available & 306 & 24.0 \\
Unfamiliarity & 119 & 9.3 \\
They are unattractive compared with exotic ornamentals & 39 & 3.0 \\
Other & 183 & 14.5 \\
Total & 1273 & 100.0 \\
\hline
\end{tabular}

$(\mathrm{SD}=2.4)$
Landscape architects noted that their demand for native plants exeds the supply currently available (Brzuszek et al., 2007). Gardeners provided as to why they do not purchase more native plants was that they could not find native 作 plants ava cient quantities of native plants available $(15.6 \%)$ (Table 3 ). As revealed in the green industry survey, over 200 
species of native plants are produced at wholesale nurseries in the southeastern United States (Brzuszek and Harkess, 2009). However, it appears that Master Gardeners perceive native plants as relatively unavailable at retail centers.

When asked why they select native plants in their purchases, the Master Gardeners' most frequent answers were that natives were better adapted to site conditions (28.7\%), because they require lower maintenance $(22.2 \%)$, and because they are useful to birds and other wildlife $(20.2 \%)$ (Table 4$)$. These closely parallel the responses provided by landscape architects as to why they select native plants in their designs: they are better adapted to site conditions $(31.2 \%)$ and require lower maintenance (18.6\%) (Brzuszek et al., 2007). Only $3 \%$ of the Master Gardeners answered that native plants are unattractive when compared with exotic ornamentals. Among these groups in the southeastern United States, the issue of natives not being as attractive as exotics is not evident, as suggested by Norcini (2006).

For Master Gardeners, the predominant ways they learn about new types, species, or cultivars of native plants is wide and varied. The most frequent sources include cooperative extension information (19.4\%), which is logical, as Master Gardeners are administered through cooperative extension agencies; through other gardeners or neighbors $(16.5 \%)$; or through conferences and public programs $(15 \%)(\mathrm{SD}=2.359)$. When asked how they best learn about native plants, they listed these same three categories in similar percentages $(\mathrm{SD}=2.423)$. Cooperative extension information scored lower with green industry and landscape architects, as found in previous surveys (Brzuszek and Harkess, 2009; Brzuszek et al., 2007). Master Gardeners responded that it would be helpful at a retail garden outlet to have native plants with descriptive signage, including growing information and use (27.0\%), described as native on the label $(23.7 \%)$, or in a designated area just for native plants arranged by landscape use (18.5\%) (Table 5). Nursery personnel responding to this question answered that individual container tags $(22.3 \%)$ or native plant brochures $(12.4 \%)$ would be most beneficial (Brzuszek and Harkess, 2009).

Table 4. Responses for the primary reasons as to why native plants are selected over exotic ornamentals as reported on a survey of Master Gardeners use of native plants conducted in 2007.

\begin{tabular}{lcc}
$\begin{array}{l}\text { Stated reasons for selecting native plants as } \\
\text { compared with exotics }\end{array}$ & $\begin{array}{c}\text { Responses } \\
\text { (no.) }\end{array}$ & $\begin{array}{c}\text { Valid } \\
\text { responses (\%) }\end{array}$ \\
\hline Aesthetics/beauty & 222 & 10.3 \\
Low maintenance & 480 & 22.2 \\
Better for backyard ecology & 314 & 14.5 \\
Use by birds or other wildlife & 436 & 20.2 \\
Better adapted to site conditions & 620 & 28.7 \\
Other & 87 & 4.0 \\
Total & 2159 & 100.0 \\
\hline
\end{tabular}

$(\mathrm{SD}=1.5)$

Table 5. Responses from Master Gardeners to "what would be useful to display native plants at retail outlets" as reported on a survey of Master Gardeners use of native plants conducted in 2007.

\begin{tabular}{lcc}
\hline $\begin{array}{l}\text { Stated responses for better display of native } \\
\text { plants at nurseries }\end{array}$ & $\begin{array}{c}\text { Responses } \\
\text { (no.) }\end{array}$ & $\begin{array}{c}\text { Valid } \\
\text { responses (\%) }\end{array}$ \\
\hline Described as native on the label & 555 & 23.7 \\
In a designated area just for native plants & 355 & 15.2 \\
In area arranged by landscape use & 432 & 18.5 \\
With descriptive signage and information & 630 & 27.0 \\
Having brochures for the public & 317 & 13.9 \\
Other & 46 & 2.0 \\
Total & 2335 & 100.0 \\
\hline
\end{tabular}

$(\mathrm{SD}=1.5)$

The top 10 native plant species purchased by Master Gardeners revealed that herbaceous plants and shrubs were the dominant types listed. This sharply contrasted with the landscape architects and green industry's answers to the same question, which were predominantly tree or shrub types, with few herbaceous plants (Brzuszek et al., 2007). Salvia (Salvia spp.), beautyberry (Callicarpa americana), azalea (Rhododendron spp.), oak-leafed hydrangea (Hydrangea quercifolia), purple cone flower (Echinacea purpurea), butterflyweed (Asclepias spp.), iris (Iris spp.), black-eye-susan (Rudbeckia spp.), eastern redbud (Cercis canadensis), and flowering dogwood (Cornus florida) were the most frequently listed as being purchased by Master Gardeners, in that order. When asked which plant species they would purchase if they were more available, Master Gardeners answered, in order of frequency, joepye weed (Eupatorium fistulosum), anise-tree (Illicium spp.), goldenrod (Solidago spp.), butterflyweed, fringedorchid (Platanthera spp.), smooth hydrangea (Hydrangea arborescens), salvia, hibiscus (Hibiscus spp.), dogwood (Cornus spp.), and azalea.

\section{Implications of the study}

The Master Gardener program is an important horticulture educational organization in the southeastern United States. Of particular note, these knowledgeable volunteers interact with the general gardening public to answer questions, give presentations and demonstrations, assist with publications, and install and maintain community landscape projects. Master Gardeners significantly influence the gardening public and the role of horticulture within their communities.

This survey revealed that Master Gardeners have an enthusiastic attitude toward the use of native plants and purchase them as a considerable part of their plant expenditures. The limitations to Master Gardeners purchasing more native plants, as also stated by landscape architects and contractors in previous studies, include lack of availability of native plants at retail outlets, few species or types available, and unavailable in sufficient quantities. Also similar in response to landscape professionals, 
the main reasons Master Gardeners use native plants includes the fact that indigenous species tend to be better adapted to difficult site conditions, they require lower maintenance, and they are useful to birds and other wildlife.

This study revealed that there are opportunities for retail nurseries to improve native plant marketing to horticultural groups such as Master Gardeners, to increase their available native plant selection, to improve labeling, and to increase quantities to better accommodate the developing native plant niche market. Providing better education materials on native plants and improved marketing may increase access to native plant materials.

\section{Literature cited}

Brzuszek, R.F. and R.L. Harkess. 2009. Green industry survey of native plant marketing in the southeastern United States. HortTechnology 19:168-172.
Brzuszek, R.F., R.L. Harkess, and S. Mulley. 2007. Landscape architects' use of native plants in the southeastern United States. HortTechnology 17:78-81.

Coffey, G. 2006. To learn about native plants, just dig right in. San Francisco Chronicle, 18 Feb. 2006. 1 Feb. 2010. <http://www.sfgate.com/cgi-bin/article. cgi?f=/c/a/2006/02/18/HOGGlH94 UDl.DTL>.

Dillman, D.A. 2007. Mail and internet surveys: The tailored design method. 2nd ed. Wiley, Hoboken, NJ.

Hamill, N. 2005. Natives near and far. Ornamental Outlook 14(6):31-32.

Harmony, F.L. com. 2008. Green Community in Florida. Harmony, Florida. 20 Feb. 2008. <http://www.harmonyfl. $\mathrm{com} />$.

Norcini, J. 2006. Native plants: An overview. Florida Coop. Ext. Serv., Inst. Food Agr. Sci., Univ. Florida ENH1045.

O’Brien, B.C. 1996. Xeriscaping: Sources of new native ornamental plants, p. 536539. In: J. Janick (ed.). Progress in new crops. ASHS Press, Arlington, VA.
Pasco County. 2002. Pasco County Landscaping and Irrigation Ordinance, No. 02-04, Section 603. I Feb. 2010. <http://www.pascocountyfl.net/devser/ $\mathrm{sd} / \mathrm{dr} / \mathrm{ldc} / 1603 . \mathrm{pdf}>$.

Stephens, J. 2002. Florida master gardener program: A brief history. Proc. Florida State Hort. Soc. 115:143-145.

U.S. Department of Agriculture. 2008. United States Department of Agriculture PLANTS database. 25 Feb. 2008. $<$ http://plants.usda.gov/>.

U.S. Fish and Wildlife Service. 2001. National wildlife refuge system: Biological integrity, diversity, and environmental health. Release no. 366. U.S. Fish and Wildlife Service Transmittal Sheet. Part 601 FW 3. U.S. Fish Wildlife Serv., Washington, DC.

U.S. National Park Service. 2000. Chapter 4: Natural resource management: 4.4.1.3 Definition of native and exotic species, p. 34. In: 2001 NPS management policies. NPS D1416. U.S. Natl. Park Serv., Washington, DC. 